\title{
INTRAVENTRICULAR PRESSURE MONITORING IN PATIENTS WITH THALAMIC AND GANGLIONIC HEMORRHAGES
}

\author{
Clement Hamani, Marcus Vinicius Zanetti, Fernando Campos Gomes Pinto, \\ Almir Ferreira Andrade, Orildo Ciquini Jr, Raul Marino Jr
}

\begin{abstract}
In the present study, we have evaluated the use of intraventricular pressure catheters in thalamic and ganglionic hemorrhages. Ten patients admitted in our Emergency Department in Glasgow Coma Scale (GCS) equal or below 13 enrolled the study (at least one point should have been lost in the eye opening score to exclude purely aphasic patients that were fully alert). After a complete clinical and neurological evaluation, computed tomography scans were obtained and the volume of the hematomas, as well as presence or absence of hydrocephalus, were considered. Intraventricular pressure catheters connected in parallel to external derivation systems were implanted and patients were thereafter sent to the ICU. Patients that presented mass effect lesions with sustained increased ICP levels or clinical and neurological deterioration were submitted in addition, to the surgical evacuation of the hematomas. Clinical evolution, complications and the rehabilitation of the patients were recorded. Clinical outcome was assessed with the Glasgow Outcome Score. In all but three patients the initial intracranial pressure levels were bellow $20 \mathrm{mmHg}$ (mean for all patients was $14.1 \pm 6.5 \mathrm{mmHg}$ ). Notwithstanding, these three patients were extremely difficult to treat. For this group of patients mortality was $100 \%$. Among the patients that presented ICP levels bellow $20 \mathrm{mmHg}, 04$ developed hydrocephalus and 03 did not display ventricular dilation. As expected, the major benefits concerning the intraventricular pressure catheters connected in parallel with external derivation systems were observed in the group of patients that presented ICP levels bellow $20 \mathrm{mmHg}$ and had hydrocephalus. Mild non-statistically significant correlations for all the three groups were achieved either when the initial GCS and ICP levels $(r=-0.28, p=0.43)$ or when ICP levels and the volumes of the hematomas were compared $(r=0.38, p=0.28)$. In addition, no significant correlations were observed concerning the final outcome of the patients and the variables previously evaluated.
\end{abstract}

KEY WORDS: intracranial pressure, thalamic and ganglionic hemorrhage, intraventricular catheters, cerebral hematomas, stroke, hypertension.

\section{Monitorizacão da pressão intraventricular em pacientes com hemorragia talâmica e dos gânglios da base}

RESUMO - No presente estudo avaliamos o uso de catéteres de monitorização intraventricular em pacientes com hemorragia talâmica e nos gânglios da base. Dez pacientes admitidos em nosso serviço de emergência com Escala de Coma de Glasgow (ECG) igual ou abaixo de 13 (com pelo menos um ponto perdido no item de abertura ocular para afastarmos pacientes alertas com afasia) foram analisados. Após uma avaliação neurológica completa, foram obtidas tomografias computadorizadas de crânio sendo desta forma avaliados o volume dos hematomas e a presença ou não de hidrocefalia. Catéteres de monitorização de pressão intraventricular, conectados em paralelo a um sistema de derivação ventricular externa (DVE) foram implantados nos pacientes, que a seguir foram levados a unidade de terapia intensiva. Pacientes cujas lesões apresentassem efeito de massa com a pressão intracraniana (PIC) elevada, a despeito das medidas clínicas utilizadas para controlá-la, ou com deterioração neurológica progressiva, foram submetidos a drenagem dos hematomas. Sete dentre os 10 pacientes deste estudo mostraram níveis de PIC abaixo de $20 \mathrm{mmHg}$ (média de 14,1 $\pm 6,5 \mathrm{mmHg}$ para todos os pacientes). Nos três restantes no entanto, a mortalidade foi muito alta pela refratariedade terapêutica (100\%). Dentre os pacientes com PIC abaixo de $20 \mathrm{mmHg}, 04$ desenvolveram hidrocefalia. Este grupo apresentou o maior benefício do implante do sistema de monitorização intraventricular com DVE. Nossa análise estatística mostrou apenas uma correlação fraca entre o (ECG) inicial e os níveis de PIC $(r=-0,28, p=0,43)$, bem como quando os níveis de PIC foram relacionados ao volume dos hematomas $(r=0,38, p=0,28)$. Correlações estatisticamente significantes também não foram encontradas quando a evolução final dos pacientes foi comparada as variáveis previamente citadas.

PALAVRAS-CHAVE: pressão intracraniana, hemorragias talâmicas e de gânglios da base, catéteres intraventriculares; AVCH, hematomas cerebrais, hipertensão.

Division of Neurosurgery, Hospital das Clínicas. University of São Paulo, São Paulo SP, Brazil.

Received 1 March 2002, received in final form 16 December 2002. Accepted 8 January 2003.

Dr. Clement Hamani - Rua Dr. Luiz Migliano 761/142c - 05711-001 São Paulo SP - Brasil.E-mail: chamani@uol.com.br 
Intracerebral hemorrhages are relatively common in neurological practice, particularly if the variety of entities that constitutes this diagnostic group is considered. Among those, ganglionic and thalamic hemorrhages receive major attention since, in addition of being prevalent, these conditions intrinsically carry prominent levels of morbidity and mortality. In therapeutic terms, although several studies have been published, there is no consensus regarding the different types of clinical and surgical procedures ${ }^{1-4}$. Nowadays it seems that, aside from a few exceptions, conservative measures in an intensive care unit and the surgical evacuation of these lesions tend to evolve similarly in terms of prognosis ${ }^{1-3,5-7}$.

Intracranial pressure (ICP) monitoring devices have recently been used in several conditions for the management not only of ICP but also cerebral perfusion pressure. Nevertheless, only a few studies submitted patients with thalamic and ganglionic hemorrhages to intracranial pressure monitoring and most of them only through subarachnoid screw devi$\mathrm{ces}^{8}$. Intraventricular catheters have the advantages of measuring the ICP more uniformly and, when connected to an external derivation system, provide a manner for decreasing ICP by draining cerebrospinal fluid $(\mathrm{CSF})^{9}$. In this sense, this procedure might be regarded as both, diagnostic and therapeutic.

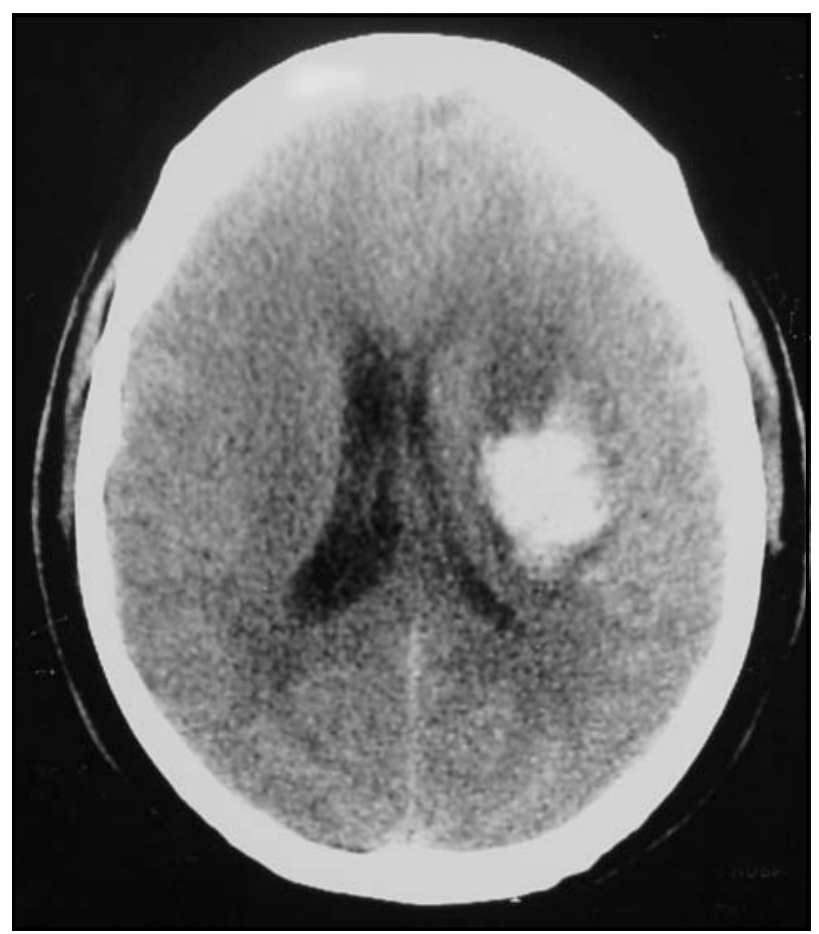

Fig 1. Initial axial CT scan from one of our patients displaying a mass effect hemorrhage with no hydrocephalus. Due to an increased ICP level, this patient was submitted to the evacuation of the hematoma but did not present a satisfactory evolution.
In the present study, we have decided to investigate the monitoring guidance and therapeutic adjuvant effects provided by the implantation of intraventricular catheters in patients with thalamic and ganglionic hemorrhages.

\section{METHOD}

Patients with ganglionic and thalamic hemorrhages enrolled in the present study were admitted in the emergency room of the University of São Paulo (HC-FMUSP) between March 2000 and January 2001, in Glasgow Coma Scale (GCS) below or equal 13 (at least one point should have been lost in the eye opening score to exclude purely aphasic patients that were fully alert). Ten patients fulfilled the criteria mentioned above. After complete clinical and neurological evaluations were peformed, computed tomography (CT) scans were regularly obtained and the volume of the hematomas, as well as presence or absence of hydrocephalus were considered. The volume of the hematomas was measured according to the formula: length $\mathrm{x}$ width $\mathrm{x}$ height $\mathrm{x} 0.5^{10-12}$. Both, length and width, were obtained from the $\mathrm{CT}$ slices demonstrating the largest hyperdense area of the hematomas. The height was determined by the number of slices in which the hematoma was clearly observed.

Surgical procedures and postoperative management Intraventricular pressure catheters connected in parallel to external derivation systems (EVD) (Camino system) were im-

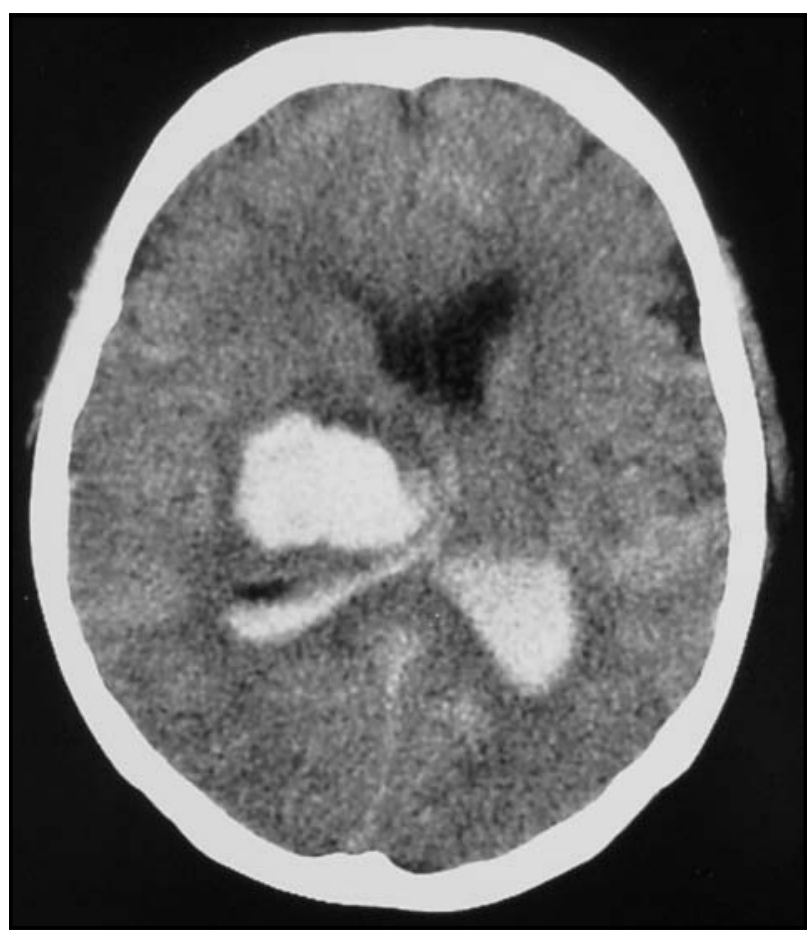

Fig 2. Initial axial CT from one of our patients displaying a nonvolumous hemorrhage with an important hydrocephalus. In this case, the ICP intraventricular catheter was not only important as a diagnostic tool concerning ICP levels, but also therapeutic. 
planted in the patients that enrolled the study. After the procedures, patients were sent to the ICU, where they received appropriate clinical treatment. Regular ICU measures to control ICP were used when pressure levels above 20 $\mathrm{mmHg}$ were reached, including the opening of the external drainage system. Patients that presented mass effect lesions with sustained increased ICP levels or clinical and neurological deterioration were submitted in addition, to the surgical evacuation of the hematomas. It is important to mention here that all catheters were tunneled and cephalhotin was used prophylactically until the removal of the systems, which occurred as soon as the patients improved or the hydrocephalus was stable. Patients that needed the intraventricular catheters for more than one week had them systematically changed. Weaving of the systems was progressively performed by elevating gradually the drift chamber of the external ventricular draining system until it could be safely closed (in our service when ICP levels were constantly bellow $15 \mathrm{mmHg}$ ). Clinical evolution, complications and the rehabilitation of the patients until they were discharged from the hospital were recorded. Clinical outcome was evaluated with the Glasgow Outcome Score (GOS). All the procedures performed in our study were approved by the ethical committee of our hospital.
Statistical analysis - Correlation and regression analysis were used to evaluate possible correlations between ICP levels, the volume of the hematomas, the initial GCS and the evolution of the patients. Correlations were respectively considered strong, moderate and mild when $r \geq 0.75$, $0.75<r \leq 0.50$ and $r<0.50$. Statistically significant regression analysis values were considered when $p \leq 0.05$.

\section{RESULTS}

The clinical and radiographic data obtained in our study, as well as the ICP levels and clinical outcome of the 10 patients evaluated are depicted in Table 1. Among the patients that enrolled our study, 07 were men and 03 were women. The mean age of our population ranged from $33-86$ years $(56.4 \pm 15.2$ years). All patients presented previous systemic hypertension, two were diabetic and one has had a previous ischemic cerebrovascular accident. All family members that were interviewed described an abrupt onset of the clinical manifestations. The period elapsed from the acute event to the patient's admission varied from 4 to 48 hours (mean $13.8 \pm 13.5$ hours). The later value was observed in a patient that was

Table 1. Clinical features, ICP levels and evolution of the patients with thalamic and ganglionic hemorrhages.

\begin{tabular}{|c|c|c|c|c|c|c|c|c|c|c|}
\hline Sex & Age & $\Delta \mathrm{t}$ & $\begin{array}{c}\mathrm{BP} \\
\mathrm{mmHg}\end{array}$ & GCS & $\begin{array}{c}\mathrm{CT} \\
\mathrm{cm} 3\end{array}$ & Hydr. & $\begin{array}{c}\mathrm{ICP} \\
\mathrm{mmHg}\end{array}$ & OR & Complications & Outcome \\
\hline \multicolumn{11}{|c|}{ ICP above $20 \mathrm{mmHg}$} \\
\hline $\mathrm{M}$ & 69 & $6 \mathrm{~h}$ & $18 \times 11$ & 10 & 32 & No & 21 & Yes & $\begin{array}{l}\text { Hypertension } \\
\text { Renal failure }\end{array}$ & Death \\
\hline M & 65 & $14 \mathrm{~h}$ & $16 \times 8$ & 11 & 36 & Yes & 23 & Yes & Pneumonia & GOS 3 \\
\hline M & 46 & $6 \mathrm{~h}$ & $16 \times 11$ & 4 & 12 & Yes & 24 & - & Sepsis & Death \\
\hline
\end{tabular}

ICP below $20 \mathrm{mmHg}$ without hydrocephalus

\begin{tabular}{|c|c|c|c|c|c|c|c|c|c|c|}
\hline $\mathrm{F}$ & 33 & $4 \mathrm{~h}$ & $16 \times 10$ & 9 & 27 & No & 12 & Yes & $\begin{array}{l}\text { Pneumonia } \\
\text { Renal failure }\end{array}$ & Death \\
\hline M & 59 & $8 \mathrm{~h}$ & $19 \times 12$ & 13 & 18 & No & 10 & - & $\begin{array}{l}\text { Pneumonia } \\
\text { Ischemic stroke } \\
\text { Renal failure } \\
\text { Sepsis }\end{array}$ & Death \\
\hline M & 58 & $5 \mathrm{~h}$ & $15 \times 9$ & 13 & 18 & No & 7 & - & - & GOS 5 \\
\hline \multicolumn{11}{|c|}{ ICP below $20 \mathrm{mmHg}$ with hydrocephalus } \\
\hline $\mathrm{F}$ & 86 & $24 \mathrm{~h}$ & $13 \times 8$ & 13 & 16 & Yes & 9 & - & - & GOS 4 \\
\hline $\mathrm{M}$ & 39 & $8 \mathrm{~h}$ & $21 \times 13$ & 7 & 18 & Yes & 8 & - & - & GOS 3 \\
\hline M & 53 & $48 \mathrm{~h}$ & $21 \times 13$ & 9 & 24 & Yes & 17 & - & $\begin{array}{l}\text { Pneumonia } \\
\text { Myocardial } \\
\text { infarction }\end{array}$ & Death \\
\hline $\mathrm{F}$ & 56 & $15 \mathrm{~h}$ & $19 \times 12$ & 4 & 27 & Yes & 10 & - & $\begin{array}{l}\text { Pneumonia } \\
\text { Ventriculitis }\end{array}$ & Death \\
\hline
\end{tabular}

$\Delta t$, time between the ictal event and admission at our service; BP, blood pressure; GCS, Glasgow coma score; CT, volume of the hematomas in $\mathrm{cm} 3$ measured according to the initial CT scan; Hydr, hydrocephalus; OR, patients submitted to the surgical evacuation of the hematomas. 
maintained in his house under familial care for two days and was brought to the hospital only after deterioration in his clinical condition and level of consciousness was noticed. All but one patient $(B P=13 \times 8)$ presented increased levels of blood pressure in the emergency room (mean systolic $17 \pm 2.6 \mathrm{mmHg}$ and diastolic $11 \pm 2.9 \mathrm{mmHg}$ ). The Glasgow Coma Scale initially obtained varied from 4 to 13 (mean of 9.3 \pm 3.4 ). No initial metabolic or coagulation dysfunction was noticed. The volume of the hematomas ranged from 12 to $36 \mathrm{~cm} 3$ (mean of $22.8 \pm 7.7$ $\mathrm{cm} 3$ ). Only a weak, non-statistically significant correlation was obtained between the volume of the hematomas and the initial GCS recorded for our patients $(r=0.05, p=0.88)$.

1 - ICP levels above $20 \mathrm{mmHg}$. In all but three patients the initial intracranial pressure levels were bellow $20 \mathrm{mmHg}$ (mean for all patients was $14.1 \pm$ $6.5 \mathrm{mmHg}$ ). Notwithstanding, these three patients were extremely difficult to treat. Two of them presented refractory ICP levels with no ventricular dilation and had their hematomas surgically removed (volumes of 32 and $36 \mathrm{~cm} 3$ ) (Figure 1). The other patients also had difficult to control ICP levels but did present hydrocephalus. As expected, all patients in this group presented very poor outcomes, developing acute renal failure, pneumonia and sepsis. For this group of patients (ICP above $20 \mathrm{mmHg}$ ) mortality was $100 \%$.

2 - ICP levels below $20 \mathrm{mmHg}$. Among the patients that presented ICP levels bellow $20 \mathrm{mmHg}$, 04 developed hydrocephalus and 03 did not display ventricular dilatation.

2.1 - ICP levels below $20 \mathrm{mmHg}$ without hydrocephalus. One of the patients initially enrolled in this group evolved with clinical deterioration and was submitted to the surgical removal of the clot but developed pneumonia, acute renal failure due to systemic hypertension and died. One of the two additional patients also deceased from a superposed ischemic cerebrovascular accident. Mortality rate for this group was therefore $67 \%$.

2.2 - ICP levels below $20 \mathrm{mmHg}$ with hydrocephalus. The major benefits concerning the intraventricular pressure catheters connected in parallel with external derivation systems were evidently observed in the group of 04 patients that presented ICP levels bellow $20 \mathrm{mmHg}$ and had hydrocephalus (Figure 2). Under these circumstances, as expected, lower mortality levels were observed ( $n=2$ or $50 \%)$. One of the patients died acutely from a myocardial infarction and the other developed ventriculitis and sepsis.
Mild non-statistically significant correlations for all the three groups were achieved either when the initial GCS and ICP levels $(r=-0.28, p=0.43)$ or when ICP levels and the volumes of the hematomas were compared $(r=0.38, p=0.28)$. In addition, no significant correlations were observed concerning the final outcome of the patients and the variables previously evaluated. The patients that were discharged from the hospital presented GOS levels of 3, 3, 4 and 5 . Those outcome levels did not change in further (3-6 months) clinical evaluations.

\section{DISCUSSION}

Our results have shown, as in other series ${ }^{1-3,8,9,13,14}$, that thalamic and ganglionar hemorrhages related to systemic hypertension are very morbid conditions ${ }^{1,2}$. Patients with initial pressures above 20 $\mathrm{mmHg}$ presented very poor outcomes, independent of the implantation of intraventricular catheters and CSF drainage. Patients with initial pressure levels bellow $20 \mathrm{mmHg}$ that did not present hydrocephalus also evolved poorly, independent of the ICP devices. Our best results were achieved in the group of patients that presented ICP levels bellow $20 \mathrm{mmHg}$ and hydrocephalus. Under these circumstances, the morbidity and mortality are better and the potential clinical aggravation related to the development of the ventricular dilation can be controlled with the external drainage device, that is also therapeutic. The optimum treatment for hypertensive ganglionar and thalamic hemorrhages is still a matter of debate ${ }^{1-3,5-7}$, particularly if we take into account the functional recovery of these patients. Although we might consider that mobility in a wheelchair and communication by gesticulation do not constitute a total disability, these achievements certainly do not represent a useful quality of life ${ }^{6}$. In this sense, several studies have been performed in order to compare the outcome of patients submitted to surgical resection of these lesion versus the ones treated exclusively with conservative measurements ${ }^{1-3,5-7,13}$. It is generally accepted that surgery for the evacuation of these hematomas per se does not provide additional functional benefits and nowadays it is only indicated for patients that present rapidly clinical deteriorating conditions ${ }^{5-7,14}$.

Important alternatives in this sense are the so called minimally invasive procedures. One of the most utilized is the stereotactic aspiration of these lesions and the local application of thrombolytic agents ${ }^{15-18}$. Despite of the good results reported by several studies $15,17,18$, these procedures still carry potential risks such as the expansion of the hematomas and rebleeding ${ }^{17}$. The- 
refore, although promising, the formal indications and some technical aspects concerning this therapeutic modality still need further improvements. The implantation of intracranial pressure monitoring devices is nowadays extensively used in several conditions for the management not only of ICP but also cerebral perfusion pressure and is considered a common procedure in almost all neurological ICUs. Nevertheless, only a few studies submitted patients with thalamic and ganglionic hemorrhages to intracranial pressure monitoring and most of them only through subarachnoid screw devices ${ }^{8}$. Intraventricular catheters have the advantages of measuring the ICP more uniformly and, when connected to an external derivation system, provide a manner for decreasing ICP by draining cerebrospinal fluid. Potential complications of this therapeutic strategy are hemorrhage during catheter placement and infection (we had one case of ventriculitis in our series) ${ }^{9,19,20}$.

Several other studies performed with external ventricular draining systems in diverse forms of cerebral and intraventricular hemorrhages did not find improvements in either morbidity or mortality, due to the severity of these conditions ${ }^{9}$. The absence of ventricular blood clots in most of our patients and the reduced size of the hematomas, as compared to studies in which intralobar, intraventricular and other intracerebral hematomas were considered, may account for the absence of therapeutic effects related to CSF drainage previously reported (as was the case for our patients in which hydrocephalus was not present). Other studies with EVD concluded that the patients with best prognosis are the ones with small $\mathrm{ICH}$ volumes (such as the ones observed in thalamic and ganglionic hemorrhages), ICP levels under control (bellow $20 \mathrm{mmHg}$ ) and stable clinical conditions $s^{8,9}$. Similarly, in our study the group of patients that presented ICP levels bellow $20 \mathrm{mmHg}$ and hydrocephalus turned out better when compared to the other ones. We believe that under these circumstances the EVD system effectively maintains the cerebral perfusion pressure and ICP under physiological conditions. Therefore, according to our results, although derived from a small sample, patients with ICP levels above $20 \mathrm{mmHg}$ tend to have a poor prognosis despite of the therapeutic measures utilized to treat them. Patients with ICP levels bellow $20 \mathrm{mmHg}$ tend to present a better prognosis, specially when hydrocephalus is present.

At this time, the ideal strategy considering the approach for these hematomas has not been developed, since the literature is still acquiring data re- lated to the improvement of the so far proposed techniques (such as stereotaxy, thrombolitic agents, among others). Although we cannot provide any resolute inferences for the management of these conditions, our results contribute to the literature providing additional data regarding a minimally invasive therapeutic approach for both, monitoring ICP and draining CSF in order to control the devastating clinical outcome produce by thalamic and ganglionic hemorrhages.

Acknowledgements - The authors wish to thank Reiko Uchizomo Simumura for the important technical assistance.

\section{REFERENCES}

1. Wityk RJ, Caplan LR. Hypertensive intracerebral hemorrhage: epidemiology and clinical pathology. Neurosurg Clin 1992;3:521-532.

2. Unwin DH, Batjer HH, Greenlee RG. Management controversy: spontaneous intracerebral hemorrhage. Neurosurg Clin 1992;3:533-537.

3. Juvela S, Heiskanen O, Poranen A, et al. The treatment of spontaneous intracerebral hemorrhage. A prospective randomized trial of surgical and conservative treatment. J Neurosurg 1989;70:755-758.

4. Bolander HG, Kourtopoulus H, Liliiequist B, Wittboldt S. Treatment of spontaneous intracerebral haemorrhage: a retrospective analysis of 74 consecutive cases with special reference of computertomographic data. Acta Neurochir 1983;67:19-28.0

5. Batjer HH, Reisch JS, Allen BC, Plaizier LJ, Su CJ. Failure of surgery to improve outcome in hypertensive putaminal hemorrhage. A prospective randomized trial. Arch Neurol 1990;47:1103-1106.

6. Fujitsu K, Muramoto M, Ikeda Y, Inada Y, Kim I, Kuwabara T. Indications for surgical treatment of putaminal hemorrhage: comparative study based on serial CT and time-course analysis. J Neurosurg 1990; 73:518-525.

7. Duff TA, Ayeni S, Levin AB, Javis M. Nonsurgical management of spontaneous intracerebral hematoma. Neurosurgery 1981;9:387-393.

8. Ropper AH, King RB. Intracranial pressure monitoring in comatose patients with cerebral hemorrhage. Arch Neurol 1984;41:725-728.

9. Adams RE, Diringer MN. Response to external ventricular drainage in spontaneous intracerebral hemorrhage with hydrocephalus. Neurology 1998;50:519-524.

10. Kothari RU, Brott TG, Broderick JP, et al. The ABCs of measuring intracerebral hematoma volumes. Stroke 1996;27:1304-1305.

11. Boto GR, Lobato RD, Rivas JJ, Gomez PA, La Lama A, Lagares A. Basal ganglia hematomas in severely head injures patients: clinicoradiological analysis of 37 cases. J Neurosurg 2001;94:224-232.

12. Wong CW. CT and clinical criteria for conservative treatment of supratentorial traumatic intracerebral hematomas. Acta Neurochir 1995;135:131-135.

13. Waga S, Yamamoto Y. Hypertensive putaminal hemorrhage: treatment and results. Is surgical treatment superior to conservative one? Stroke 1983;14:480-485.

14. Kanno T, Sano H, Shinomiya $Y$, et al. Role of surgery in hypertensive intracerebral hematoma: a comparative study of 305 nonsurgical and 154 surgical cases. J Neurosurg 1984;61:1091-1099.

15. Lippitz BE, Mayfrank L, Spetzger U, Warnke JP, Bertalanffy H, Gilsbach JM. Lysis of basal ganglia haematoma with recombinant tissue plasminogen activator (rtPA) after steterotactic aspiration: initial results. Acta Neurochir 1994;127:157-160.

16. Mayfrank L, Kissler J, Raoofi R, et al. Ventricular dilation in experimental hemorrhage in pigs: characterization of cerebrospinal fluid dynamics and the effects of fibrinolytic treatment. Stroke 1997;28:141-148.

17. Montes JM, Wong JH, Fayad PB, Awad IA. Stereotactic computed tomographic-guided aspiration and thrombolysis of intracerebral hematoma: protocol and preliminary experience. Stroke 2000;31:834-840.

18. Niizuma H, Shimizu Y, Yonemitsu T, Nakasato N, Suzuki J. Results of stereotactic aspiration of 175 cases of putaminal hemorrhage. Neurosurgery 1989;24:814-819.

19. Backlund EO, von Holst H. Controlled subtotal evacuation of intracerebral haematomas by stereotactic technique. Surg Neurol 1978;9:99-101.

20. Chan K, Mann KS. Prolonged therapeutic external ventricular drainage: a prospective study. Neurosurgery 1988;23:436-438. 